\title{
PENINGKATAN KETERAMPILAN KOLABORASI PADA MATA PELAJARAN MATEMATIKA KELAS 4 SD N GENDONGAN 03 MELALUI PENERAPAN MODEL PEMBELAJARAN TEAMS GAMES TOURNAMENT (TGT )
}

\author{
Halimah $^{1}$, Mawardi ${ }^{2}$, Krisma Widi Wardani $^{3}$ \\ 1,2,3 Program Studi PGSD, Universitas Kristen Satya Wacana \\ email : 292015120@student.uksw.edu
}

\begin{abstract}
ABSTRAK
Penelitian ini bertujuan untuk meningkatkan keterampilan kolaborasi siswa dalam ilmu Matematika dengan menerapkan model pembelajaran kooperatife tipe TGT( Teams Games Tournament) dengan langkah-langkah penyajian kelas, Tim, Permainan, Pertandingan dan Penghargaan Kelompok. Penelitian ini adalah Penenitian Tindakan Kelas yang dilakukan dalam dua siklus dengan 20 siswa kelas empat di sekolah dasar salatiga di semester kedua tahun akademik 2019/2020. Data dikumpulkan dengan menggunakan teknik angket.Hasil menunjukkan peningkatan keterampillan kolaborasi dengan menerapkan model model pembelajaran kooperatife tipe TGT pada mata pelajaran ilmu Matematika. Pada Kelengkapan rata-rata keterampilan kolaborasi meningkat dari pra siklus ke siklus II. Pada pra siklus adalah $65 \%$ mengalami peningkatan pada siklus 1 sebesar $75 \%$ dengan kategori sangat tinggi. Pada siklus II mengalami peningkatan sebesar $90 \%$ yang memiliki kategori sangat tinggi. Oleh karena itu model TGT dapat meningkatkan keterampilan kolaborasi dalam ilmu matematika.
\end{abstract}

Kata Kunci : Keterampilan Kolaborasi,Kooperatife., TGT( Teams Games Tournament).

\begin{abstract}
This study aimed determining student collaboration skills in Mathematics by applying the cooperative learning Teams Games Tournament (TGT) model with steps in presenting classes, Teams, Games, Games and Group Awards. This research was a type of a classroom action research wich was conducted in two cycles in 20 fourth grade students in a primary school in the second semester of the 2019/2020 academic year. Data was collected using questionnaire techniques. The results show improvement in the effectiveness of collaboration by applying the TGT cooperative learning model model on Mathematics subjects. The average complete collaboration skill increases from pre cycle to cycle II. In the pre cycle, $65 \%$ experienced an increase in the first cycle of $75 \%$ with a very high category. In the second cycle there was an increase of $90 \%$ which had a very high category. Therefore, Applying the TGT model can improve the collaboration skills in mathematics.
\end{abstract}

Keywords: Collaboration Skill, Cooperative, TGT( Teams Games Tournament) 


\section{Pendahuluan}

Matematika merupakan hal yang mendasari perkembangan teknologi dan berbagai disiplin ilmu untuk memajukan daya pikir manusia melalui pengalaman serta penggunaan benda konkrit (Dyah Ismayanti, 2006:5). Hal itu bisa dilihat dengan mata pelajaran matematika yang memiliki peranan penting dalam disiplin ilmu pengetahuan dan memejukan daya pikir manusia. Matematika berhubungan erat dengan ide, aturan, serta hubungan antar ide itu diatur secara logis maka matematika akan bekaitan erat dengan konsep-konsep abstrak (Wahyudi, 2012: 10). Adapun dari pendapat lain mengatakan bahwa matematika merupakan ilmu pengetahuan yang mempelajari struktur yang bersifat abstrak dan segala pola didalamnya (Heruman, 2007: 27) Hasil observasi terhadap pembelajaran di SD N Gendongan 03 ditemukan bahwa metode atau model pembelajaran yang digunakan selama ini masih ceramah, dan jarang pada pembelajaran matematika menggunakan pendekatan dan model pembelajaran, sehingga dalam pembelajaran siswa cenderung pasif hanya mendengarkan penjelasan guru serta mengerjakan soal - soal yang diberikan oleh guru. Hal ini akan memberi dampak yang kurang baik bagi siswa, karena siswa belajar hanya untuk ulangan atau ujian, sehingga pembelajaran kurang menarik dan membosankan bagi siswa, terkadang siswa juga mengantuk pada saat pembelajaran yang akhirnya bermuara pada rendahnya prestasi belajar yang diperoleh siswa serta siswa tidak percaya diri mengutarakan pendapatnya di depan kelas

Teori Dienes ini menempatkan suatu pembelajaran dalam sebuah permainan yang akan merangsang keinginan siswa untuk ingin tahu dan lebih semangat lagi dalam belajar. Dalam permainan ini ada kaitanya dengan keterampilan kolaborasi yaitu dapat diterapkan dalam berbagai bidang studi, terutama dalam mata pelajaran yang bertujuan membentuk kemampuan interpersonal untuk belajar secara berkelompok atau sesi perkuliahan yang membutuhkan belajar bersama atau berkelompok yang tidak dapat diselesaikan secara individual. Keterampilan kolaboorasi ini dalam pembelajaran menggunakan model pembelajaran kooperatife tipe TGT(Teams games Tournament). Dalam pembelajaran TGT peserta didik memainkan permaianan dengan anggota-anggota tim lain untuk memperoleh skor bagi tim mereka masing- masing. Permaianan dapat disusun guru dalam bentuk kuis berupa pertanyaan- pertanyaan yang berkaitan dengan materi pelajaran. lima komponen dalam model pembelajaran TGT sebagai berikut.a.Penyajian Kelas:Penyajian kelas digunakan untuk memperkenalkan materi pelajaran dengan pengajaran langsung,diskusi ataupun audiovisual. b.Tim : Tim terdiri dari 4 sampai 6 peserta didik anggota kelas dengan kemampuan yang berbeda, c.Game/permainan: Permainan didesain untuk menguji pengetahuan yang ingin dicapai peserta didik dan biasanya disususn dalam pertanyaan yang sama dengan materi dalam presentasi kelas. Permainan dilakukan oleh 3 atau 4 peserta didik yang berkemampuan antara masing-masing mewakili tim yang berbeda.d.Turnamen / pertandingan:Turnamen adalah saat dimana permainan berlangsung biasanya turnamanen dilaksanakan pada setiap minggu akhir /unit setelah guru memberikan presentasi kelas dan setiap tim berhasil dengan lembar kegiatan siswa. e. Penghargaan kelompok ( Team Recognition )Langkah pertama sebelum memberikan penghargaan kelompok adalah menghitung rata-rata skor dalam kelompok. Model TGT ini dapat meningkatkan kemampuan siswa untuk bekerjasama dan berkolaborasi, melatih kepekaan diri siswa, empati dan keberanian dalam berkompetisi dan juga bekerjasama dengan teman-teman dalam satu kelas.

Penelitian yang relevan dengan penelitian ini adalah penelitian yang dilakukan oleh Atik Liunin Huna ( 2010 )menunjukkan bahwa dapat meningkatkan hasil belajar mereka, seperti dalam model pembelajaran kolaborasi. Hasil penelitian menunjukkan ini menunjukkan bahwa dapat meningkatkan hasil belajar. Penelitian yang dilakukan oleh Yanti Purnamasari ( 2013 ). Pengaruh Model Pembelajaran Kooperatif Tipe Team Games Tournament ( TGT ) Terhadap kemandirian belajar dan peningkatan kemampuan penalaran dan koneksi Matematika peserta didik SMP N 1 Kota Tasikmalaya. Hasil peneltian dan pembahasan juga menunjukkan pembelajaran TGT lebih baik meningkatkan kemampuan penalaran dan koneksi matematika peserta didik dari pada pembelajaran langsung. Penelitian yang dilakukan oleh Soviawati, E. 
(2011). Pendekatan matematika realistik (pmr) untuk meningkatkan kemampuan berfikir siswa di tingkat sekolah dasar mengalami peningkatan. Penelitian yang dilakukan oleh Yenni Agustina(2015 ). Perbandingan hasil belajar siswa yang diajarkan dengan menggunakan model pembelajaran kolaborasi dan quantum teaching pada materi pajak siswa Kelas VIII smpn 1 makmur.

\section{Metode}

Penelitian ini adalah penelitian tindakan kelas dengan menggunakan model TGT (Teams Games Tournament).Penelitian ini dilakukan di SDN Gendongan 03 Kota Salatiga, dengan subjek penelitian Kelas 4 yang terdiri dari 12 siswa pria dan 18 siswa wanita. Variabel independen dalam penelitian ini adalah pembelajaran matematika sedangkan variabel dependen dalam penelitian ini adalah keterampilan kolaborasi. Data dikumpulkan menggunakan angket. Angket diberikan kepada siswa untuk mengukur keterampilan kolaborasi melalui observasi dan catatan lapangan . Di akhir masing-masing siklus, siswa mengisi angket untuk mengetahui tingkat kolaborasi siswa. Data dianalisis secara deskriptif dengan membandingkan kebermaknaan dan pembelajaran di hasil siswa di Siklus I dan Siklus II.

\section{Hasil Dan Pembahasan}

Berdasarkan hasil observasi dan wawancara dengan guru kelas 4 SD N Gendongan 03 yang dilakukan peneliti, ditemukan beberapa hal diantaranya: 1) model pembelajaran yang digunakan selama ini masih ceramah,2).pada pembelajaran matematika menggunakan pendekatan dan model pembelajaran,3).dalam pembelajaran siswa cenderung pasif hanya mendengarkan penjelasan guru. Dari hasil studi dokumen nilai siswa terdapat 7 dari 20 siswa yang mendapat nilai di bawah KKM (61) yaitu dibawah untuk muatan pelajaran Matematika. Sehingga kemampuan dalam bekerja sama tidak nampak. Untuk meningkatkan keterampilan kolaborasi siswa mennggunakan model pembelajaran kooperatife tipe TGT(Teams Games Tournament) dalam pembelajaran Matematika.

Peneliti membuat skenario pembelajaran dan media pembelajaran. Peneliti juga menyiapkan instrumen peneliti berupa rencana pelaksanaan pembelajaran (RPP), soal setiap pertemuan pada siklus 1 , menyiapkan soal post test siklus 1 , menyiapkan instrumen observasi kegiatan guru dan siswa di siklus 1, peneliti menjelaskan materi tentang keliling dan luas bangun datar,kemudian siswa latihan menjawab soal-soal yang di sediakan oleh guru. Pada pertemuan 2 media yang digunakan berupa kartu soal dan jawaban untuk permainan model TGT, peneliti juga menyiapkan papan skor , serta hadiah untuk siswa. Peneliti menjelaskan materi keliling dan luas bngun datar menyediakan media pembelajaran.

Dalam pelaksanan peneliti menggunakan 3 jam pelajaran untuk satu kali pertemuan, Materi yang dipelajari adalah mengenai konsep keliling dan luas bangun datar.Guru menggunakan kartu soal untuk mengerjakan soal secara individu tetapi dalam tim yang diacak. Guru turut serta membantu kelompok atau individu yang mengalami kesulitan.. Siswa atau kelompok yang memiliki skor paling banyak akan mendapatkan bintang sebagai hadiah di siklus 1. Pada Siklus I kemampuan berkolaborasai siswa mengalami peningkatan. Hasil keterampilan kolaborasi siswa dalam siklus I meningkat dari $65 \%$ menjadi $75 \%$.

Solusi yang diambil guru untuk melakukan perbaikan disiklus II adalah; Guru akan menjelaskan kembali mengenai konsep luas dan keliling bangun datar menggunakan akar pangkat menggunakan permainan TGT. Guru akan membimbing siswa untuk berdiskusi dengan teman dan saling bertukar ide dan informasi. Setelah dilakukan perbaikan pada siklus II, terlihat bahwa pada siklus II berjalan sesuai dengan apa yang diharapkan. Terjadi peningkatan pada siklus 1 rata-rata keterampilan kolaborasi siswa $75 \%$ dengan kategori sangat tinggi. Pada siklus II mengalami peningkatan sebesar $90 \%$ yang memiliki kategori sangat tinggi . Kegiatan Siklus II ini dapat dikatakan berhasil, karena terjadi peningkatan keterampilan 
kolaborasi sebesar 15\%. Dengan demikian maka dapat dilihat perubahan peningkatan keterampilan kolaborasi yang telah dikenai model pembelajaran TGT.

Tabel 1. Perbandingan Keterampilan kolaborasi Pra Siklus, Siklus I, dan Siklus II

\begin{tabular}{lccccccc}
\hline & & \multicolumn{2}{c}{ Pra Siklus } & \multicolumn{2}{c}{ Siklus I } & Siklus II \\
\cline { 3 - 8 } \multicolumn{1}{c}{ Interval } & Kategori & $\begin{array}{c}\text { Jumla } \\
\mathrm{h}\end{array}$ & $\begin{array}{c}\text { Persen } \\
\text { tase }\end{array}$ & $\begin{array}{c}\text { Ju } \\
\text { mla } \\
\text { h }\end{array}$ & $\begin{array}{c}\text { Persentas } \\
\text { e }\end{array}$ & Jumlah & Persentase \\
\hline Sangat Tinggi & $\geq 58$ & 13 & $65 \%$ & 15 & $75 \%$ & 18 & $90 \%$ \\
Tinggi & $43 \leq 57$ & 4 & $20 \%$ & 4 & $20 \%$ & 2 & $10 \%$ \\
Sedang & $29 \leq 42$ & 3 & $15 \%$ & 1 & $5 \%$ & 0 & $0 \%$ \\
Rendah & $14 \leq 28$ & 0 & $0 \%$ & 0 & $0 \%$ & 0 & $0 \%$ \\
& & 20 & $100 \%$ & 20 & $100 \%$ & 20 & $100 \%$ \\
\hline
\end{tabular}

Dari Tabel diatas dapat dilihat bahwa keterampilan kolaborasi matematika yang dikenai tindakan model pembelajaran TGT (Teams Games Tournament) mengalami peningkatan. Untuk lebih jelasnya dapat dilihat dari diagram berikut:

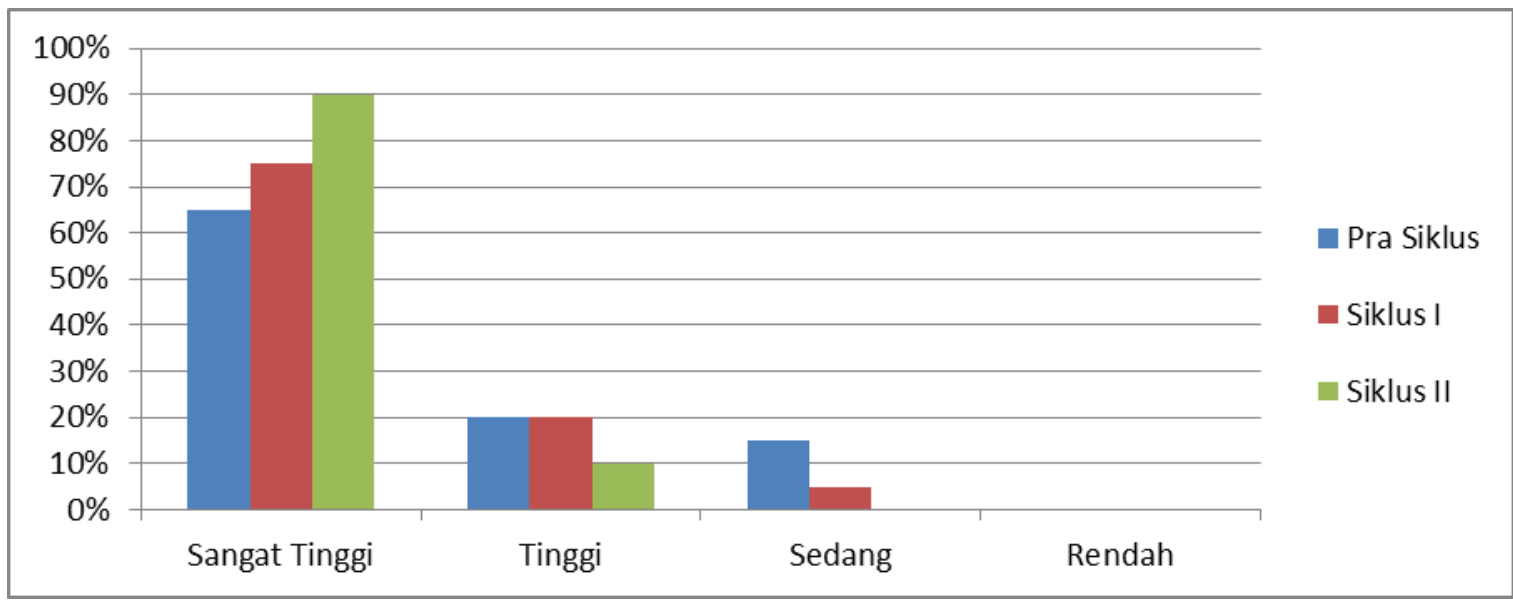

Diagram 1. Diagram Peningkatan Kemampuan Berpikir Kritis Matematika Pra Siklus, Siklus I, Dan Siklus II

Diagram tersebut menjelaskan bahwa tingkat keterampilan kolaborasi siswa dari pra siklus sampai siklus 1 mengalami peningkatan. Pada pra siklus keterampilan kolaborasi (13 siswa dari 20 siswa) memiliki keterampilan kolaborasi sangat tinggi yaitu $65 \%$, (4 siswa dari 20 siswa) memiliki keterampilan kolaborasi tinggi yaitu $20 \%$, (3 siswa dari 20 siswa) memiliki keterampilan kolaborasi sedang yaitu $15 \%$, (0 siswa dari 20 siswa) memiliki keterampilan kolaborasi rendah yaitu $0 \%$. Pada siklus I(15 dari 20 siswa) memiliki keterampilan kolaborasi sangat tinggi yaitu $75 \%$, (4 siswa dari 20 siswa) memiliki keterampilan kolaborasi tinggi yaitu $25 \%$, (1 siswa dari 20 siswa) memiliki keterampilan kolaborasi sangat tinggi yaitu $5 \%$, (0 siswa dari 200 siswa) memiliki keterampilan kolaborasi sangat tinggi yaitu 0\%. Pada siklus II (18 siswa dari 20 siswa) memiliki keterampilan kolaborasi sangat tinggi yaitu $95 \%$, (2 siswa dari 20 siswa) memiliki keterampilan kolaborasi tinggi yaitu $10 \%$, (0 siswa dari 20 siswa) memiliki keterampilan kolaborasi sedang yaitu $0 \%$. (0 siswa dari 20 siswa) memiliki keterampilan kolaborasi rendah yaitu $0 \%$. 
Berdasarkan observasi dan refleksi tindakan yang telah dilakukan oleh guru, pelaksanaan tindakan pembelajaran pada pelajaran Matematika dengan menggunakan model pembelajaran TGT telah berjalan sesuai dengan yang diharapkan. Penggunaan model pembelajaran TGT juga terbukti dapat meningkatkan ketrampilan kolaborasi siswa kelas 4 SD Negeri Gendongan 03 Salatiga pada mata pelajaran Matematika. Hasil Penelitian ini sejalan dengan penelitian yang dilakukan oleh Keke Citra Wahyu Avisca ( 2018 ). Peningkatan Critical Thinking dan Collaborative skill Matematika melalui model Group Investigation berbantuab Magic Ball.

Hasil penelitian menunjukkan adanya peningkatan keterampilan Critical Thinking dan Collaborative skill terlihat dari peningkatan total skor perserta didik setiap siklus mengalami peningkatan. Penerapan Model pembelajaran Kooperatife Tipe TGT ( Team Games Tournamen ) Dalam materi pokok Logaritma Guna meningkatkan Motivasi Belajar dan Hasil Belajar Peserta Didik Kelas X A MAN Semarang 2 Semester Gasal Tahun Pelajaran 2009/ 2010. Penelitian yang dilakukan Dewi Susilowati (2004) yang berjudul "Pengaruh Metode Pembelajaran Kooperatif Tipe Teams-GamesTournament (TGT) Terhadap Prestasi Belajar Belajar Matematika Ditinjau dari Motivasi Belajar Siswa SLTP Negeri Se Kecamatan Sukoharjo". Hasil dari penelitian tersebut adalah terdapat perbedaan prestasi belajar matematika yang signifikan yaitu metode pembelajaran kooperatif tipe I TGT lebih baik dibandingkan dengan siswa yang mengikuti pembelajaran matematika secara konvensional. Penelitian yang dilakukan oleh Hindarso (2009) yang berjudul "Eksperimentasi Pembelajaran Matematika dengan Model Pembelajaran Kooperatif Tipe Teams Games Tournament (TGT) pada Materi Pokok Rumus-Rumus Trigonometri ditinjau dari Aktivitas Belajar Peserta Didik SMA Negeri Kota Surakarta. Hasil dari penelitian ini adalah secara umum penggunaan model pembelajaran kooperatif tipe TGT menghasilkan prestasi belajar matematika yang lebih baik daripada model pembelajaran kooperatif tipe NHT.

\section{Simpulan dan Saran}

Berdasarkan penelitian yang sudah dilakukan dengan menggunakan model pembelajaran TGT(Teams games Tournament) untuk meningkatkan kerampilan kolaborasi siswa kelas 4 SD Negeri Gendongan 03 Salatiga, maka dapat disimpulkan bahwa model pembelajran TGT dapat meningkatkan keterampilan kolaborasi siswa. Dalam kegiatan pembelajaran matematika terlihat bahwa siswa cenderung pasif.Setelah dilakukan tindakan pada siklus 1 Dengan pembelajaran menggunakan kartu soal membuat siswa lebih antusias dan tertarik untuk belajar. Pada Siklus I kemampuan berkolaborasai siswa mengalami peningkatan. Hasil keterampilan kolaborasi siswa dalam siklus I meningkat dari $65 \%$ menjadi $75 \%$. Terjadi peningkatan pada siklus 1 rata-rata keterampilan kolaborasi siswa 75\% dengan kategori sangat tinggi. Pada siklus II mengalami peningkatan sebesar $90 \%$ yang memiliki kategori sangat tinggi.Kegiatan Siklus II ini dapat dikatakan berhasil, karena terjadi peningkatan keterampilan kolaborasi sebesar $15 \%$.

Penelitian tindakan kelas yang dilaksanakan sudah memenuhi keberhasilan yang sudah ditetapkan terjadi peningkata pada keterampilan kolaborasi.Pada indikator proses pelaksanaan model TGT juga sudah terlaksana $100 \%$. Sehingga pelaksanaan penelitian/ tindakan kelas ini dapat disimpulkan bahwa penerapan model TGT dapat meningkatkan keterampilan kolaborasi siswa. 


\section{Daftar Rujukan}

Agustina, Y. (2017). Perbandingan Hasil Belajar Siswa Yang Diajarkan Dengan Menggunakan Model Pembelajaran Kolaborasi Dan Quantum Teaching Pada Materi Pajak Siswa Kelas VIII Smpn 1 Makmur. Jurnal Sain Ekonomi Dan Edukasi (Jsee), 3(1), 81-93.

Ana, A., \& Rohaeni, N. (2013). Pengembangan Tugas Akhir Melalui Project

Based Learning Model Untuk Meningkatkan Generic Green Skills Siswa. Jurnal Pendidikan Teknologi Dan Kejuruan, 21(3) 25-34.

Avisca, K. C. W., Mawardi, M., \& Astuti, S. (2018). Peningkatan Critical Thinking Dan Collaborative Skill Matematika Melalui Model Group Investigation Berbantuan Magic Ball. Naturalistic: Jurnal Kajian Penelitian Pendidikan Dan Pembelajaran, 2(2), 129-138.

Devi, V. P., Wahyudi, W., \& Indarini, E. (2018). Penerapan Metode Numbered Heads Together Berbantuan Puzzle Untuk Meningkatkan Keterampilan Kolaborasi Dan Hasil Belajar Tema 8 Daerah Tempat Tinggalku siswa Kelas 4 Sdn 3 Kuripan. Kalam Cendekia Pgsd Kebumen, 6(3.1), 42-51.

Hasan, A. (2006). Model Pembelajaran Menulis Artikel Melalui Workshop dan Kolaborasi (Doctoral dissertation, Universitas Pendidikan Indonesia). Maulidah, S. F. (2013). Upaya Meningkatkan Hasil Belajar Siswa Mata Pelajaran IPA Melalui Metode Kooperatif Tipe Teams-Games-Tournament (Tgt) Kelas 4 Sdn Karanganyar 01 Semester I Tahun Pelajaran 2012/2013 (Doctoral Dissertation, Program Studi Pendidikan Guru Sekolah Dasar Pskgdj Fkip-Uksw).

Sari, K. A., Prasetyo, Z. K., \& Wibowo, W. S. (2017). Pengembangan Lembar Kerja Peserta Didik Ipa Berbasis Model Project Based Learning Untuk Meningkatkan Keterampilan Kolaborasi Dan Komunikasi Peserta Didik Kelas Vii Development Of Science Student Worksheet Based On Project Based Learning Model To Improve Collaboration And Communication Skills Of Junior High School Student. Pend. Ilmu Pengetahuan AlamS1, 6(8), 461-467.

Soviawati, E. (2011). Pendekatan Matematika Realistik (Pmr) Untuk Meningkatkan Kemampuan Berfikir Siswa Di Tingkat Sekolah Dasar. Jurnal Edisi Khusus, 2(2), 79-85.

Purnamasari, Y. (2013). Pengaruh Model Pembelajaran Kooperatif Tipe Teams GamesTournament (Tgt) Terhadap Kemandirian Belajar Dan Peningkatan Kemampuan Penalaran Dan Koneksi Matematik Peserta Didik Smpn 1 Kota Tasikmalaya (Doctoral Dissertation, Universitas Terbuka)

Putra, F. G. (2015). Eksperimentasi Model Pembelajaran Kooperatif Tipe Teams Games Tournament (Tgt) Berbantuan Software Cabri 3d Di Tinjau Dari Kemampuan Koneksi Matematis Siswa. Al-Jabar: Jurnal Pendidikan Matematika, 6(2), 143-154.

Wilujeng, S. (2013). Peningkatan Aktivitas Dan Hasil Belajar Siswa Melalui Model Teams Games Tournament (TGT). Journal of Elementary Education, 2(1). 
Zubaidah, S. (2016, December). Keterampilan Abad Ke 21: Keterampilan Yang Diajarkan Melalui Pembelajaran. In Disampaikan Pada Seminar Nasional Pendidikan Dengan Tema "Isu-Isu Strategis Pembelajaran Mipa Abad (Vol. 21).Muhsetyo, G., Krisnadi, E., \& Wahyuningrum, E. (2014). Pembelajaran Matematika Sd 